\title{
Synthesis, Characterization, and Application of Europium(III) Complexes as Luminescent Markers of Banknotes
}

\author{
Clebson J. Macrino, ${ }^{a, b}$ Elias M. Silva, ${ }^{a}$ Victor R. Cunha, ${ }^{c}$ Victor R. Fonseca, ${ }^{a}$ Álvaro Cunha Neto, ${ }^{\circledR a}$ \\ Joyce R. Araújo, ${ }^{c}$ Valdemar Lacerda Jr. ${ }^{\circledR *, a}$ and Wanderson Romão ${ }^{\oplus *, a, b, d}$ \\ ${ }^{a}$ Laboratório de Petroleômica e Forense, Universidade Federal do Espírito Santo (UFES), \\ Avenida Fernando Ferrari, 514, Goiabeiras, 29075-910 Vitória-ES, Brazil \\ ${ }^{b}$ Instituto Nacional de Ciências e Tecnologia Forense (INCT Forense), \\ Av. Ipiranga, 6681, Partenon, 90619-900 Porto Alegre-RS, Brazil \\ ${ }^{c}$ Divisão de Metrologia de Materiais, Instituto Nacional de Metrologia, Qualidade e Tecnologia, \\ Av. Nossa Senhora das Graças, 50, 25250-020 Duque de Caxias-RJ, Brazil \\ ${ }^{d}$ Instituto Federal do Espírito Santo (IFES), Av. Ministro Salgado Filho, Soteco, \\ 29106-010 Vila Velha-ES, Brazil
}

In this work, three complexes were synthesized from the trivalent europium ion $\left(\mathrm{Eu}^{\mathrm{III}}\right)$, using the picrate anion (pic), and delta-valerolactam (DVL), epsilon-caprolactam (EPK), and oenantholactam $(\mathrm{OEN})$. The synthesized complexes $\left[\mathrm{Eu}(\mathrm{pic})_{3} \cdot(\mathrm{DVL})_{3}\right],\left[\mathrm{Eu}(\mathrm{pic})_{3} \cdot(\mathrm{EPK})_{3}\right]$, and $\left[\mathrm{Eu}(\mathrm{pic})_{3} \cdot(\mathrm{OEN})_{3}\right]$ were studied as luminescent markers for application as security elements in Brazilian banknotes. All complexes showed red color emission with absorption at $397 \mathrm{~nm}$ and emission at $614 \mathrm{~nm}$. Qualitative luminescence tests were performed on $\mathrm{R} \$ 10, \mathrm{R} \$ 20, \mathrm{R} \$ 50$, and $\mathrm{R} \$ 100$ Brazilian banknotes. The complexes were applied on the surface of the banknotes and were exposed to different wavelengths of $254,312,365$, and 320-400 $\mathrm{nm}$. The chemical profiles of the complexes were identified on the banknotes employing the laser desorption ionization mass spectrometry (LDI ( \pm ) MS) technique. Generally, tests were promising, and can thus provide a simple, fast, and easy method to identify the authenticity of questioned documents, with an average cost of R\$0.65 per $\mathrm{mg}$.

Keywords: counterfeiting, luminescent markers, europium(III) complexes, LDI MS

\section{Introduction}

Documentoscopy or detection of forgery is the branch of forensic chemistry dealing with the study of questioned documents to verify their authenticity. It has a role in criminalistics, not only to determine the veracity of documents but also to discover the authorship of falsifications and the means that were employed..$^{1-3}$

The falsification of documents is characterized as a crime of intelligence, and within the field of documentoscopy, banknotes, stamps, national driving licenses, identity cards, vehicle registration certificates, vehicle licensing certificates, credit cards, and checks stand out as primary targets of frauds. ${ }^{4}$ Within this context, the use of different analytical techniques is reported in the literature to determinate authenticity, such as gas chromatography

*e-mail: vljuniorqui@gmail.com; wandersonromao@gmail.com coupled to mass spectrometry (GC-MS) and Fourier transform infrared (FTIR) spectroscopy to determine the ages of documents, ${ }^{5,6}$ video spectral comparator (VSC) to establish trace release order, ${ }^{7}$ and ultraviolet-visible (UV-Vis) spectroscopy for the differentiation of italic letters. ${ }^{8}$

The advancement of digital technologies in copying equipment, printing, and image processing has facilitated the falsification of documents, and the quality of falsified documents can be practically indistinguishable from the original document. ${ }^{9}$ Therefore, the development of efficient and rapid analytical techniques to determine authenticity is necessary. Typically, the techniques used include atomic force microscopy, ${ }^{10}$ FTIR spectroscopy, ${ }^{11}$ Raman spectroscopy, ${ }^{12-14}$ GC-MS, ${ }^{15}$ ESI MS (electrospray ionization mass spectrometry), ${ }^{16}$ LDI MS (laser desorption ionization mass spectrometry), ${ }^{17-19}$ and ambient ionization mass spectrometry techniques EASI MS (easy ambient 
sonic-spray ionization mass spectrometry), PSI MS (paper spray ionization mass spectrometry), DESI MS (desorption electrospray ionization mass spectrometry), and DART MS (direct analysis in real time mass spectrometry). ${ }^{20-24}$ Among the types of forgery employed, the counterfeiting of banknotes deserves particular attention, since this is an increasingly common financial crime, both in the sense of increasing the number of falsified records and in the diversity of the falsification methods used by the falsifiers. ${ }^{25,26}$ In addition, this type of crime can affect the economy of several countries. Therefore, the use of efficient security items such as security papers, latent images, watermarks, magnetic strips, special printing techniques, holograms, and areas with infrared (IR) or ultraviolet (UV) light responses has been adopted as a form of fingerprinting for authentic banknotes. ${ }^{27}$

It is of great importance to use security items that are easily and quickly identified by the population to prevent counterfeiting of banknotes. For this purpose, the use of new photoluminescent materials that emit light in the presence of electromagnetic radiation in the IR or UV region gains prominence because these materials meet the requirement of simple and rapid identification. New materials incorporating lanthanides ${ }^{28-37}$ may be potential photoluminescent markers for the authenticity of banknotes.

The luminescent property of lanthanide ions mainly originates from transitions involving partially occupied $4 \mathrm{f}$ orbitals. The luminescence phenomenon using direct excitation of the lanthanide ion is inefficient because it does not have high molar absorptivity. The light is absorbed by an organic molecule (ligand), which transfers energy to the lanthanide ion, which then emits luminescence resulting from intra-configuration transitions of orbital $4 \mathrm{f}$ and usually observed in the visible region. Hence, there is an intra-molecular energy transfer from the ligand to the metal ion known as the "antenna effect". 38,39

This luminescent ability of the lanthanide complexes, to absorb and emit radiation with characteristic wavelengths, defines these materials as light conversion molecular devices (DMCLs). The efficiency of the transfer of energy from the binder to the lanthanide ion depends on the chemical nature of the coordinated ligand..$^{40}$ Among the lanthanide(III) ions, the elements europium, terbium, and thulium emit in the regions of visible red, green, and blue light, respectively. ${ }^{41,42}$ The luminescent properties of materials derived from these metals have broad applicability in several areas, including their use as bio-detectors, ${ }^{43,44}$ films, ${ }^{45}$ solar cells, ${ }^{46}$ and organic light-emitting diode (OLED) ${ }^{47}$ and, in the forensic field, in the detection of explosives, ${ }^{28}$ fingerprints, ${ }^{48,49}$ and gunshot residues. ${ }^{50,51}$
A series of lanthanide(III) picrate (pic) complexes with different organic molecules as coligands are reported in the literature. Silva et $a l . .^{52}$ described the preparation of a complex isomorphous with hexamethylphosphoramide (HMPA), with the formula $\left[\mathrm{Ln}(\mathrm{pic})_{3} \cdot(\mathrm{HMPA})_{3}\right](\mathrm{Ln}=\mathrm{Nd}$, $\mathrm{Eu})$. Miranda Jr. et al. ${ }^{53}$ reported the characterization of the structure with composition $\left[\operatorname{Ln}(\text { pic })_{3} \cdot(\text { DTSO })_{3}\right]$ $(\mathrm{Ln}=\mathrm{La}-\mathrm{Yb}, \mathrm{Y})$, using 1,3-dithiane-1-oxide (DTSO) as a coligand. Melo et al. ${ }^{54}$ synthesized lanthanide(III) picrate complexes with $\mathrm{N}, \mathrm{N}$-dimethylacetamide (DMA), with the composition $\left[\mathrm{Ln}(\mathrm{pic})_{3} \cdot(\mathrm{DMA})_{3}\right](\mathrm{Ln}=\mathrm{La}, \mathrm{Eu}, \mathrm{Gd}, \mathrm{Sm}, \mathrm{Lu})$. Nunes et al. ${ }^{55}$ reported a complex with 3-picoline- $N$-oxide (3-picNO) and the formula $\left[\mathrm{Eu}(\mathrm{pic})_{3} \cdot(3-\mathrm{picNO})_{2} \cdot\left(\mathrm{H}_{2} \mathrm{O}\right)\right]$. Marinho et al..$^{56}$ described a synthesis utilizing pyrazine$\mathrm{N}$-oxide (pyzNO) obtaining compounds with the composition $\left[\mathrm{Ln}(\text { pic })_{3} \cdot(\text { pyzNO })_{2} \cdot\left(\mathrm{H}_{2} \mathrm{O}\right)_{7}\right](\mathrm{Ln}=\mathrm{Nd}$, $\mathrm{Eu})$. Destefani et al. ${ }^{57}$ reported a compound using $\mathrm{N}$-methylcaprolactam (NMK) as coligand with the formula $\left[\mathrm{Eu}(\mathrm{pic})_{3} \cdot(\mathrm{NMK})_{3}\right]$.

This work reports the synthesis, characterization, and application of three new europium(III) picrate complexes, using three different lactams (delta-valerolactam, epsiloncaprolactam, and oenantholactam) as coligands, for luminescent markers of Brazilian $\mathrm{R} \$ 10, \mathrm{R} \$ 20, \mathrm{R} \$ 50$, and $\mathrm{R} \$ 100$ banknotes.

\section{Experimental}

\section{Materials}

Ethanol, hydrochloric acid $(\mathrm{HCl})$, ethylenediaminetetraacetic acid (EDTA) and urea (analytical grade with purity higher than 99.5\%) were supplied by Vetec Química Fina Ltda, Duque de Caxias, RJ, Brazil. $\mathrm{Eu}_{2} \mathrm{O}_{3}(99.9 \%)$, picric acid (pic) $\mathrm{C}_{6} \mathrm{H}_{3} \mathrm{~N}_{3} \mathrm{O}_{7}(99.9 \%$ ), delta-valerolactam (DVL) $\mathrm{C}_{5} \mathrm{H}_{9} \mathrm{NO}$ (98\%), epsilon-caprolactam (EPK) $\mathrm{C}_{6} \mathrm{H}_{11} \mathrm{NO}$ (98\%), and oenantholactam (OEN) $\mathrm{C}_{7} \mathrm{H}_{13} \mathrm{NO}(98 \%)$ were supplied by Sigma-Aldrich Chemicals, St. Louis, USA.

The chemical stoichiometry of the complexes was determined through complexometric titration with $0.01 \mathrm{~mol} \mathrm{~L}^{-1}$ EDTA standard solution ${ }^{58}$ and elemental analysis using a Thermo Fisher Scientific Flash 1112-CHNS-O (Waltham, Massachusetts, USA). The infrared spectra were obtained in transmittance mode with an attenuated total reflectance accessory (ATR) in the region of 4000-650 $\mathrm{cm}^{-1}$, using a PerkinElmer FTIR Spectrum 400 MID/NIR spectrometer (Waltham, Massachusetts, USA) at room temperature. UVVis region spectroscopy analyses were performed for the solid-state complexes using a PerkinElmer spectrometer (Waltham, Massachusetts, USA), in the range of $220-800 \mathrm{~nm}$. Excitation spectra were obtained at room temperature in the 
range of $250-550 \mathrm{~nm}$, with a slot opening of 0.75 , monitoring the intensity of the ${ }^{5} \mathrm{D}_{0} \rightarrow{ }^{7} \mathrm{~F}_{2}$ transition at $616 \mathrm{~nm}$. Emission spectra were obtained in the range of $550-750 \mathrm{~nm}$ at room temperature, with a slot opening of 0.75 and excitation at $397 \mathrm{~nm}$, using a Quanta Master 40 spectrofluorometer (Edison, New Jersey, USA) with a $75 \mathrm{~W}$ xenon lamp. Determinations of the exact masses of the complexes were made by laser desorption ionization mass spectrometry in both ionization modes, LDI ( \pm ) MS, using an FT-ICR model 9.4 T Solarix mass spectrometer, Bruker Daltonics (Bremen, Germany), equipped with a Smartbeam-II ${ }^{\mathrm{TM}}(355 \mathrm{~nm})$ laser. LDI $( \pm)$ MS data were acquired with 16 scans with a frequency of $200 \mathrm{~Hz}$ in the range of $m / 2$ 200-1200, using 100 laser shots per pixel, a small (ca. $30 \mu \mathrm{m})$ laser focus setting, and laser power ranging from 13 to $15 \%$.

\section{Synthesis}

Synthesis of hydrated europium(III) picrate $\left[\mathrm{Eu}(\mathrm{pic})_{3} \cdot\left(\mathrm{H}_{2} \mathrm{O}\right)_{11}\right]$ Initially, hydrated basic carbonate of europium(III), $\mathrm{EuCO}_{3}(\mathrm{OH}) \cdot \mathrm{xH}_{2} \mathrm{O}$, was obtained from $\mathrm{Eu}_{2} \mathrm{O}_{3}(5.0 \mathrm{~g})$ and concentrated hydrochloric acid was added to the oxide suspension in water $(800 \mathrm{~mL})$. The solution was heated $\left(85-90{ }^{\circ} \mathrm{C}\right)$ and urea was added until the solution reached a $\mathrm{pH}$ of approximately 7 . Basic carbonate hydrate of europium(III) with a yield of $91 \%$ was obtained as a product, and $2.0 \mathrm{~g}$ of this compound was then suspended in an aqueous medium $(100 \mathrm{~mL})$. This solution was heated $\left(85-90{ }^{\circ} \mathrm{C}\right)$ and picric acid was added until all basic carbonate was consumed. The resulting solution was filtered and allowed to stand at room temperature for crystallization. The obtained crystals had yellow coloration and were dried at room temperature and stored in an amber bottle. ${ }^{59}$ Yield 79\%; anal. calcd. $(\%)$ for $\left[\mathrm{Eu}(\text { pic })_{3} \cdot\left(\mathrm{H}_{2} \mathrm{O}\right)_{11}\right]$ : C 20.90, H 2.73, N 12.19, Eu ${ }^{\mathrm{III}}$ 14.70, found: C 20.60, H 2.50, N 11.83, Eu ${ }^{\mathrm{III}} 15.50$; FTIR-ATR $v / \mathrm{cm}^{-1} 1558_{(\mathrm{s})}$ $v_{\text {ass }} \mathrm{NO}_{2}, 1335_{(\mathrm{s})} v_{\mathrm{s}} \mathrm{NO}_{2}, 797_{(\mathrm{m})} \gamma \mathrm{CH}$, for free picric acid (Figure 1a) $1526_{(\mathrm{s})} v_{\text {ass }} \mathrm{NO}_{2}, 1539_{(\mathrm{s})} v_{\mathrm{s}} \mathrm{NO}_{2}, 782_{(\mathrm{m})} \gamma \mathrm{CH}$.

\section{Synthesis of complexes}

The compounds were prepared by dissolving the hydrated europium(III) picrate in ethanol with an ethanolic solution of the lactam (molar ratio 1:3, lactam $=$ DVL, EPK, and OEN). Triethyl orthoformate, which is used as a dehydrating agent, was then added, contributing to the removal of hydration waters from the europium(III) picrate. The system was stirred until a yellow solid appeared. The solid obtained was washed with ethyl ether, dried at room temperature, and stored in an amber bottle..$^{60}$ The results of experimental and calculated elemental analysis and FTIR analysis of the complexes were as follows:

Europium(III) picrate with delta-valerolactam $\left[\mathrm{Eu}(\text { pic })_{3} \cdot(\mathrm{DVL})_{3}\right]$

Yield 63\%; anal. calcd. (\%) for $\mathrm{C}_{33} \mathrm{H}_{33} \mathrm{~N}_{12} \mathrm{O}_{24} \mathrm{Eu}$ : C 34.87, H 2.93, N 14.79, Eu ${ }^{\mathrm{III}}$ 13.40, found: C 35.88, $\mathrm{H} 3.09, \mathrm{~N} 14.39, \mathrm{Eu}^{\mathrm{III}}$ 13.37; FTIR-ATR $v / \mathrm{cm}^{-1}$ (Figure 1c) $2956_{(\mathrm{s})} v \mathrm{NH}, 1599_{(\mathrm{s})} v \mathrm{C}=\mathrm{O}, 1534_{(\mathrm{s})} v_{\text {ass }} \mathrm{NO}_{2}, 1318_{(\mathrm{s})} v_{\mathrm{s}} \mathrm{NO}_{2}$, $785_{(\mathrm{m})} \gamma \mathrm{CH}$, for free DVL (Figure 1b) $2951_{(\mathrm{s})} v \mathrm{NH}, 1637_{(\mathrm{s})}$ $\nu \mathrm{C}=\mathrm{O}$.

Europium(III) picrate with epsilon-caprolactam $\left[\mathrm{Eu}(\mathrm{pic})_{3} \cdot(\mathrm{EPK})_{3}\right]$

Yield 68\%; anal. calcd. (\%) for $\mathrm{C}_{36} \mathrm{H}_{39} \mathrm{~N}_{12} \mathrm{O}_{24} \mathrm{Eu}$ : C 36.69, H 3.33, N 14.26, Eu ${ }^{\mathrm{III}} 12.93$, found: C 37.39, $\mathrm{H} 3.39, \mathrm{~N}$ 14.34, Eu ${ }^{\mathrm{III}}$ 13.01; FTIR-ATR $\mathrm{v} / \mathrm{cm}^{-1}$ (Figure 1e) $2935_{(\mathrm{s})} v \mathrm{NH}, 1607_{(\mathrm{s})} v \mathrm{C}=\mathrm{O}, 1534_{(\mathrm{s})} v_{\text {ass }} \mathrm{NO}_{2}, 1324_{(\mathrm{s})} v_{\mathrm{s}} \mathrm{NO}_{2}$, $790_{(\mathrm{m})} \gamma \mathrm{CH}$, for free EPK (Figure 1d) $2930_{(\mathrm{s})} v \mathrm{NH}, 1647_{(\mathrm{s})}$ $\nu \mathrm{C}=\mathrm{O}$.

Europium(III) picrate with oenantholactam $\left[\mathrm{Eu}(\mathrm{pic})_{3} \cdot(\mathrm{OEN})_{3}\right]$

Yield 72\%; anal. calcd. (\%) for $\mathrm{C}_{39} \mathrm{H}_{45} \mathrm{~N}_{12} \mathrm{O}_{24} \mathrm{Eu}$ : C 38.43, H 3.69, N 13.79, Eu ${ }^{\mathrm{III}} 12.48$, found: C 38.46,
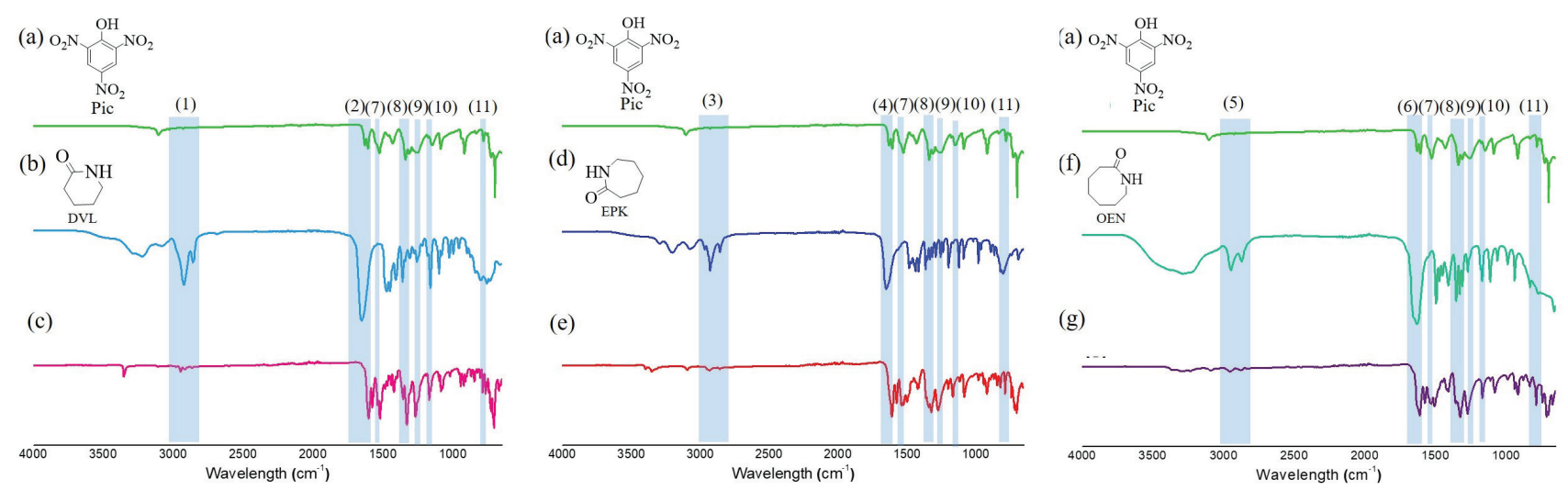

Figure 1. FTIR-ATR spectra of (a) pic: $v_{\text {ass }} \mathrm{NO}_{2}(7), v_{\mathrm{as}} \mathrm{NO}_{2}(8), v \mathrm{C}-\mathrm{O}(9), \gamma \mathrm{OH}(10), \gamma \mathrm{CH}(11) ;$ (b) DVL: $v \mathrm{NH}(1), v \mathrm{C}=\mathrm{O}(2) ;$ (c) $\left[\mathrm{Eu}(\mathrm{pic})_{3} \cdot(\mathrm{DVL})_{3}\right]: v \mathrm{NH}$ (1), $v \mathrm{C}=\mathrm{O}(2), v_{\text {ass }} \mathrm{NO}_{2}(7), v_{\mathrm{as}} \mathrm{NO}_{2}(8), v \mathrm{C}-\mathrm{O}(9), \gamma \mathrm{CH}(11)$; (d) $\mathrm{EPK}: v \mathrm{NH}(3), v \mathrm{C}=\mathrm{O}$ (4); (e) [ $\left.\mathrm{Eu}(\mathrm{pic})_{3} \cdot(\mathrm{EPK})_{3}\right]: v \mathrm{NH}(3), v \mathrm{C}=\mathrm{O}(4), v_{\mathrm{ass}} \mathrm{NO}_{2}(7), v_{\mathrm{as}} \mathrm{NO}_{2}$ (8), $v \mathrm{C}-\mathrm{O}(9), \gamma \mathrm{CH}$ (11); (f) OEN: $v \mathrm{NH}(5), v \mathrm{C}=\mathrm{O}(6)$; (g) [Eu(pic) $\left.)_{3} \cdot(\mathrm{OEN})_{3}\right]: v \mathrm{NH}(5), v \mathrm{C}=\mathrm{O}(6), v_{\text {ass }} \mathrm{NO}_{2}(7), v_{\mathrm{as}} \mathrm{NO}_{2}(8), v \mathrm{C}-\mathrm{O}(9), \gamma \mathrm{CH}(11)$. 
H 3.70, N 13.80, Eu ${ }^{\text {III } 12.40 ; ~ F T I R-A T R ~} v / \mathrm{cm}^{-1}$ (Figure 1g) $2940_{(\mathrm{s})} v \mathrm{NH}, 1604_{(\mathrm{s})} v \mathrm{C}=\mathrm{O}, 1554_{(\mathrm{s})} v_{\text {ass }} \mathrm{NO}_{2}, 1335_{(\mathrm{s})} v_{\mathrm{s}} \mathrm{NO}_{2}$, $783_{(\mathrm{m})} \gamma \mathrm{CH}$, for free OEN (Figure 1f) $2924_{(\mathrm{s})} v \mathrm{NH}, 1655_{(\mathrm{s})}$ $\nu \mathrm{C}=\mathrm{O}$.

The syntheses of the three complexes are represented schematically in Figure 2.

\section{Application of complexes in Brazilian banknotes}

A total of six Brazilian banknotes were used: one each in the values of $\mathrm{R} \$ 10, \mathrm{R} \$ 20$, and $\mathrm{R} \$ 100$, and three $\mathrm{R} \$ 50$ notes. The notes were purchased from a Brazilian bank. The $\mathrm{R} \$ 10$ and $\mathrm{R} \$ 20$ banknotes were chosen because they are more commonly used; the $\mathrm{R} \$ 50$ and $\mathrm{R} \$ 100$ banknotes were chosen because they have greater value and are major targets of counterfeiting. For the R $\$ 50$ banknotes, approximately $1 \mathrm{mg}$ of each complex was applied using a swab and deposited on the surface of the banknotes at the top of the region that contained the value of each banknote. Later, the complex that showed the best photoluminescence (in this case the $\left[\mathrm{Eu}(\mathrm{pic})_{3} \cdot(\mathrm{EPK})_{3}\right]$ ) was applied to the other three (i.e., $\mathrm{R} \$ 10, \mathrm{R} \$ 20$, and $\mathrm{R} \$ 100)$ banknotes. Complexes were applied to the areas showing the respective monetary values of the banknotes. Qualitative analyses of the photoluminescence were evaluated using a Video Spectral Comparator VSC ${ }^{\circledR} 6000$ (Foster \& Freeman, Worcestershire, United Kingdom), operated at 254, 312 and $365 \mathrm{~nm}$, and a Lumatec Superlite 400 (Deisenhofen, Germany), with excitation between 320-400 nm.

\section{Results and Discussion}

\section{Synthesis}

Hydrated basic carbonates of europium(III) were prepared by precipitation from homogeneous solutions via the hydrolysis of urea without the addition of an auxiliary anion, ${ }^{61}$ allowing the formation of hydrated europium(III) picrate by the direct reaction of hydrated basic carbonate of europium(III) with picric acid. This process obtained a high yield and a non-hygroscopic compound.

The stoichiometry of the complexes was obtained through elemental analysis (CHN), which confirmed the $1: 3$ molar ratio $\left(\left[\mathrm{Eu}(\mathrm{pic})_{3} \cdot\left(\mathrm{H}_{2} \mathrm{O}\right)_{11}\right]\right.$ :lactam $)$. FTIR spectra (Figure 1) identified the presence of asymmetric stretching frequencies $\left(v_{\text {ass }} \mathrm{NO}_{2}\right.$ (region 7)) and symmetrical frequencies $\left(v_{\mathrm{s}} \mathrm{NO}_{2}\right.$ (region 8)) for the picrate ion, demonstrating the coordination of this ion to the metallic center of the europium(III). The split and shifted $v_{\mathrm{s}} \mathrm{NO}_{2}$ vibration suggested that the picrate ions are coordinated to the metallic center in a bidentate form, through the phenolic oxygen atom and the $o$-nitro group oxygen atom. The disappearance of the out-of-plane vibration of the $\mathrm{OH}$ (region 10) group at $1151 \mathrm{~cm}^{-1}$, corresponding to free picric acid, indicates that hydrogen has been replaced by the $\mathrm{Eu}^{\mathrm{III}}$ ion and that phenolic oxygen coordination to $\mathrm{Eu}^{\mathrm{III}}$ has occurred. The $v \mathrm{C}-\mathrm{O}$ (region 9) vibration shift from 1260 to $1274 \mathrm{~cm}^{-1}$ suggests that the substitution of phenolic hydrogen $(\mathrm{OH})$ by $\mathrm{Eu}^{\mathrm{III}}$ increases the $\pi$ character of the $\mathrm{C}-\mathrm{O}$ bond. ${ }^{62-64}$ In addition, the $\nu \mathrm{C}=\mathrm{O}$ (regions 2,4 , and

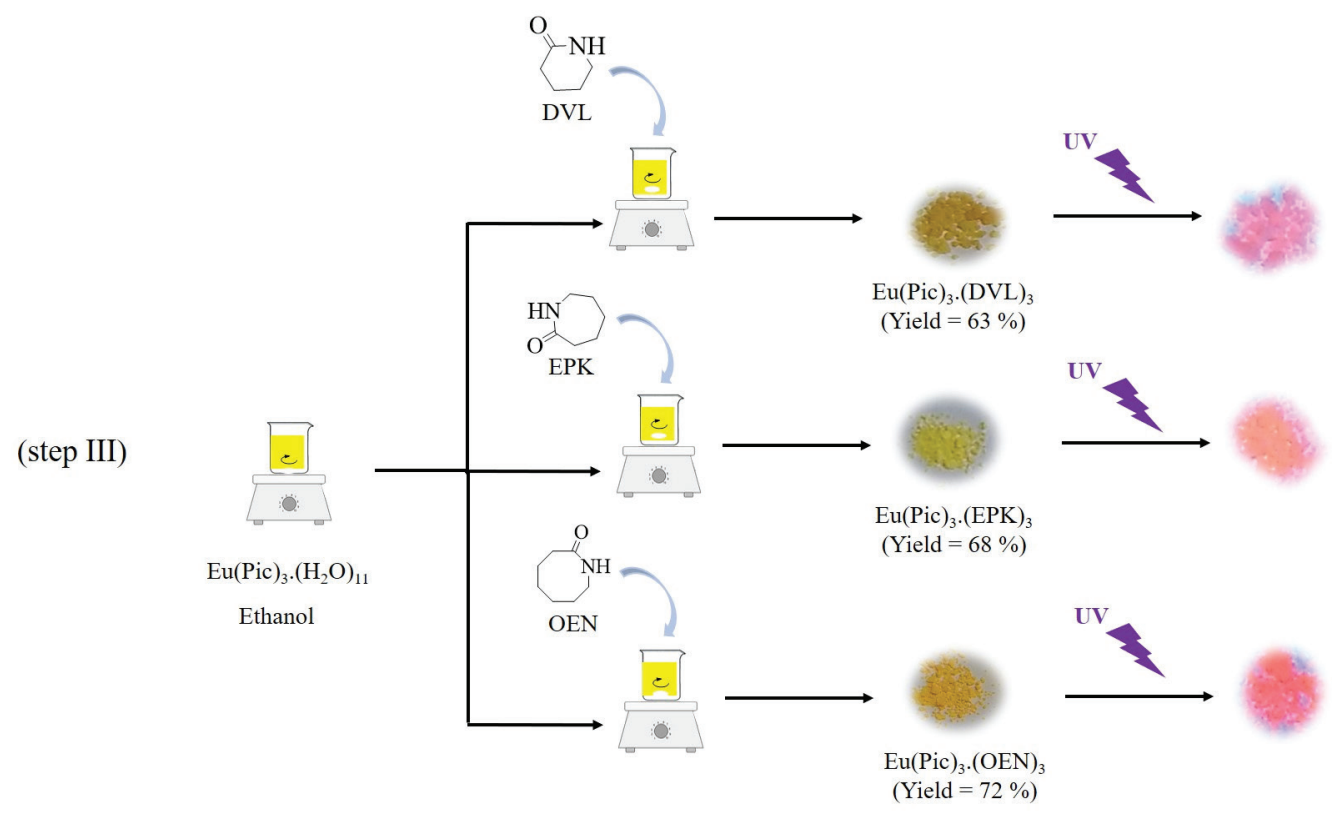

Figure 2. Scheme of the syntheses of the studied $\mathrm{Eu}^{\mathrm{III}}$ complexes. 
6) vibration shift for lower energy regions and decreased intensity of $v \mathrm{NH}$ (regions 1,3 , and 5) stretching of lactams, concerning the free ligand, suggests the coordination of carbonyl to the $\mathrm{Eu}^{\mathrm{III}}$ ion. ${ }^{65}$

\section{Emission and excitation analysis}

The UV-Vis absorption spectra of $\left[\mathrm{Eu}(\mathrm{pic})_{3^{3}} \cdot(\mathrm{DVL})_{3}\right]$ in Figure S1a (Supplementary Information (SI) section) and $\left[\mathrm{Eu}(\mathrm{pic})_{3} \cdot(\mathrm{EPK})_{3}\right]$ complexes in Figure S1c (SI section) show bands with maximum absorption at 323 and $324 \mathrm{~nm}$, respectively, which can be attributed to intra-ligand $\pi \rightarrow \pi^{*}$ type electronic transitions, and a band with maximum intensity at $391 \mathrm{~nm}$, which was observed for both, attributed to $\mathrm{n} \rightarrow \pi^{*}$-type transitions. For the $\left[\mathrm{Eu}(\mathrm{pic})_{3} \cdot(\mathrm{OEN})_{3}\right]$ complex in Figure S1b (SI section), a single broad band with a maximum intensity at $361 \mathrm{~nm}$ was observed and can be attributed to the overlapping $\pi \rightarrow \pi^{*}$ and $n \rightarrow \pi^{*}$ transitions. In addition, a low-intensity band around $740 \mathrm{~nm}$ was observed for all complexes and is assigned to the $\mathrm{f}-\mathrm{f}$ transitions of the ${ }^{7} \mathrm{~F}_{5} \rightarrow{ }^{5} \mathrm{D}_{0}$ type for the Eu ${ }^{\mathrm{III}}$ ion. ${ }^{66}$

The excitation spectra in Figure S2 (SI section) presented a broad band between $250-500 \mathrm{~nm}$, which can be attributed to the central ligand (maximum at $397 \mathrm{~nm}$ ) and characterized as the transition band of the ligands $\left(\mathrm{S}_{0} \rightarrow \mathrm{S}_{1}\right)$. The excitation at $397 \mathrm{~nm}$ is very close to the ${ }^{5} \mathrm{~L}_{6}$ level of the Eu ${ }^{\text {III }}(394 \mathrm{~nm})$. The excitation spectra exhibit a broad band between $250-500 \mathrm{~nm}$, overlapping the ${ }^{5} \mathrm{~L}_{6}$ level. Therefore, the ${ }^{5} \mathrm{~L}_{6}$ level can also be an efficient channel for the photoluminescence of the compounds, although lanthanide ions have low absorption coefficients.

The emission spectra in Figure 3 of the compounds at room temperature showed the regions of the $\mathrm{f}-\mathrm{f}$ transitions from the excited level ${ }^{5} \mathrm{D}_{0} \rightarrow{ }^{7} \mathrm{~F}_{\mathrm{J}}(\mathrm{J}=0,1$, 2, 3, and 4): ${ }^{5} \mathrm{D}_{0} \rightarrow{ }^{7} \mathrm{~F}_{0}(576 \mathrm{~nm}),{ }^{5} \mathrm{D}_{0} \rightarrow{ }^{7} \mathrm{~F}_{1}(590 \mathrm{~nm})$, ${ }^{5} \mathrm{D}_{0} \rightarrow{ }^{7} \mathrm{~F}_{2}(614 \mathrm{~nm}),{ }^{5} \mathrm{D}_{0} \rightarrow{ }^{7} \mathrm{~F}_{3}(650 \mathrm{~nm})$, and ${ }^{5} \mathrm{D}_{0} \rightarrow{ }^{7} \mathrm{~F}_{4}$ $(696 \mathrm{~nm})$, with maximum emission at $614 \mathrm{~nm}$. The band corresponding to the ${ }^{5} \mathrm{D}_{0} \rightarrow{ }^{7} \mathrm{~F}_{0}$ transition was observed to have weak intensity. The presence of this band suggests that the $\mathrm{Eu}^{3+}$ ion is involved in a low-symmetry chemical environment, which may be of $\mathrm{C}_{\mathrm{n}}, \mathrm{C}_{\mathrm{s}}$, or $\mathrm{C}_{\mathrm{nv}}$ type. ${ }^{67}$ The ${ }^{5} \mathrm{D}_{0} \rightarrow{ }^{7} \mathrm{~F}_{2}$ transition is a hypersensitive transition with a predominantly electric dipole character, and when its intensity is higher than that of the ${ }^{5} \mathrm{D}_{0} \rightarrow{ }^{7} \mathrm{~F}_{1}$ transition, this indicates that the compounds have no inversion center. The low intensity of the ${ }^{5} \mathrm{D}_{0} \rightarrow{ }^{7} \mathrm{~F}_{0}$ transition associated with the intensity presented by the ${ }^{5} \mathrm{D}_{0} \rightarrow{ }^{7} \mathrm{~F}_{4}$ transition can be interpreted in terms of the symmetry of the $\mathrm{Eu}^{\mathrm{III}}$ ion chemical environment, suggesting that it is in a highly polarizable chemical environment with distorted symmetry. ${ }^{68}$ The experimental intensity parameters $\Omega_{\lambda}$
( $\lambda=2$ and 4 ) in Table 1 were determined from the emission spectra for the compounds based on the ${ }^{5} \mathrm{D}_{0} \rightarrow{ }^{7} \mathrm{~F}_{2}$ and ${ }^{5} \mathrm{D}_{0} \rightarrow{ }^{7} \mathrm{~F}_{4}$ transitions, with the ${ }^{5} \mathrm{D}_{0} \rightarrow{ }^{7} \mathrm{~F}_{1}$ magnetic-dipoleallowed transition as the reference because this transition is practically insensitive to changes in the chemical environment. They are estimated according to equation $1: 69$

$$
\Omega_{\lambda}=\frac{3 \mathrm{hc}^{3} \mathrm{~A}_{0 \rightarrow \mathrm{J}}}{4 \mathrm{e}^{2} \omega^{3} \chi\left\langle{ }^{5} \mathrm{D}_{0}\left\|\mathrm{U}^{(\lambda)}\right\|^{7} \mathrm{~F}_{\mathrm{J}}\right\rangle^{2}}
$$

where $e$ is the electronic charge, $\omega$ is the angular frequency of the transition, $\hbar$ is Planck's constant divided by $2 \pi$, c is the velocity of light, and $\chi=n\left(n^{2}+2\right)^{2} / 9$ is the Lorentz local field correction term with a refraction index $\mathrm{n}$ of 1.5. The squared reduced matrix elements are $\left\langle{ }^{5} \mathrm{D}_{0}\left\|\mathrm{U}^{(2)}\right\|^{7} \mathrm{~F}_{2}\right\rangle^{2}=0.0032$ and $\left\langle{ }^{5} \mathrm{D}_{0}\left\|\mathrm{U}^{(4)}\right\|^{7} \mathrm{~F}_{4}\right\rangle^{2}=0.0023 .^{70,71}$ The $\Omega_{6}$ parameter was not determined because the ${ }^{5} \mathrm{D}_{0} \rightarrow{ }^{7} \mathrm{~F}_{6}$ transition could not be experimentally detected. It occurs in the near IR (ca. $840 \mathrm{~nm}$ ) and thus beyond the detection range of the experimental setup. The $\Omega_{2}$ and $\Omega_{4}$ intensity parameters for the complexes are presented in Table 1. In this case, the Einstein coefficient values of spontaneous emission between ${ }^{5} \mathrm{D}_{0} \rightarrow{ }^{7} \mathrm{~F}_{\mathrm{J}}\left(\mathrm{A}_{0 \lambda}\right)$ are obtained using equation 2 :

$$
\mathrm{A}_{0 \lambda}=\mathrm{A}_{01} \frac{\mathrm{S}_{0 \lambda}}{\mathrm{S}_{01}} \frac{v_{01}}{v_{0 \lambda}}
$$

where $S_{0 \lambda}$ is the area under the emission curve related to the ${ }^{5} \mathrm{D}_{0} \rightarrow{ }^{7} \mathrm{~F}_{\mathrm{J}}$ transitions obtained from the spectral data, and $v_{0 \lambda}$ is the energy barycenter of the transitions from the ${ }^{5} \mathrm{D}_{0}$ excited state to the ${ }^{7} \mathrm{~F}_{1},{ }^{7} \mathrm{~F}_{2}$, and ${ }^{7} \mathrm{~F}_{4}$ ground states (in $\mathrm{cm}^{-1}$ ). The ${ }^{5} \mathrm{D}_{0} \rightarrow{ }^{7} \mathrm{~F}_{1}$ magnetic-dipole-allowed transition is almost independent of the crystal field environment around the $\mathrm{Eu}^{\mathrm{III}}$ ion (the $\mathrm{A}_{01}$ value is estimated to be approximately $50 \mathrm{~s}^{-1}$ ). ${ }^{72}$

Table 1. Experimental intensity parameters $\Omega_{2}$ and $\Omega_{4}$ calculated for the compounds

\begin{tabular}{lcc}
\hline Compound & $\Omega_{2} /\left(10^{-20} \mathrm{~cm}^{2}\right)$ & $\Omega_{4} /\left(10^{-20} \mathrm{~cm}^{2}\right)$ \\
\hline$\left.[\text { Eu(pic })_{3} \cdot\left(\mathrm{H}_{2} \mathrm{O}\right)_{11}\right]$ & 11.38 & 7.45 \\
{$\left[\mathrm{Eu}(\text { pic })_{3} \cdot(\mathrm{DVL})_{3}\right]$} & 16.17 & 7.41 \\
{$\left[\mathrm{Eu}(\text { pic })_{3} \cdot(\mathrm{EPK})_{3}\right]$} & 17.90 & 7.15 \\
{$\left[\mathrm{Eu}(\mathrm{pic})_{3} \cdot(\mathrm{OEN})_{3}\right]$} & 15.76 & 7.29 \\
\hline
\end{tabular}

pic: picrate anion; DVL: delta-valerolactam; EPK: epsilon-caprolactam; OEN: oenantholactam.

The experimental intensity parameter $\Omega_{2}$ shows different values for the compounds in Table 1, indicating that the $\mathrm{Eu}^{\mathrm{III}}$ ions are in different chemical environments and that 

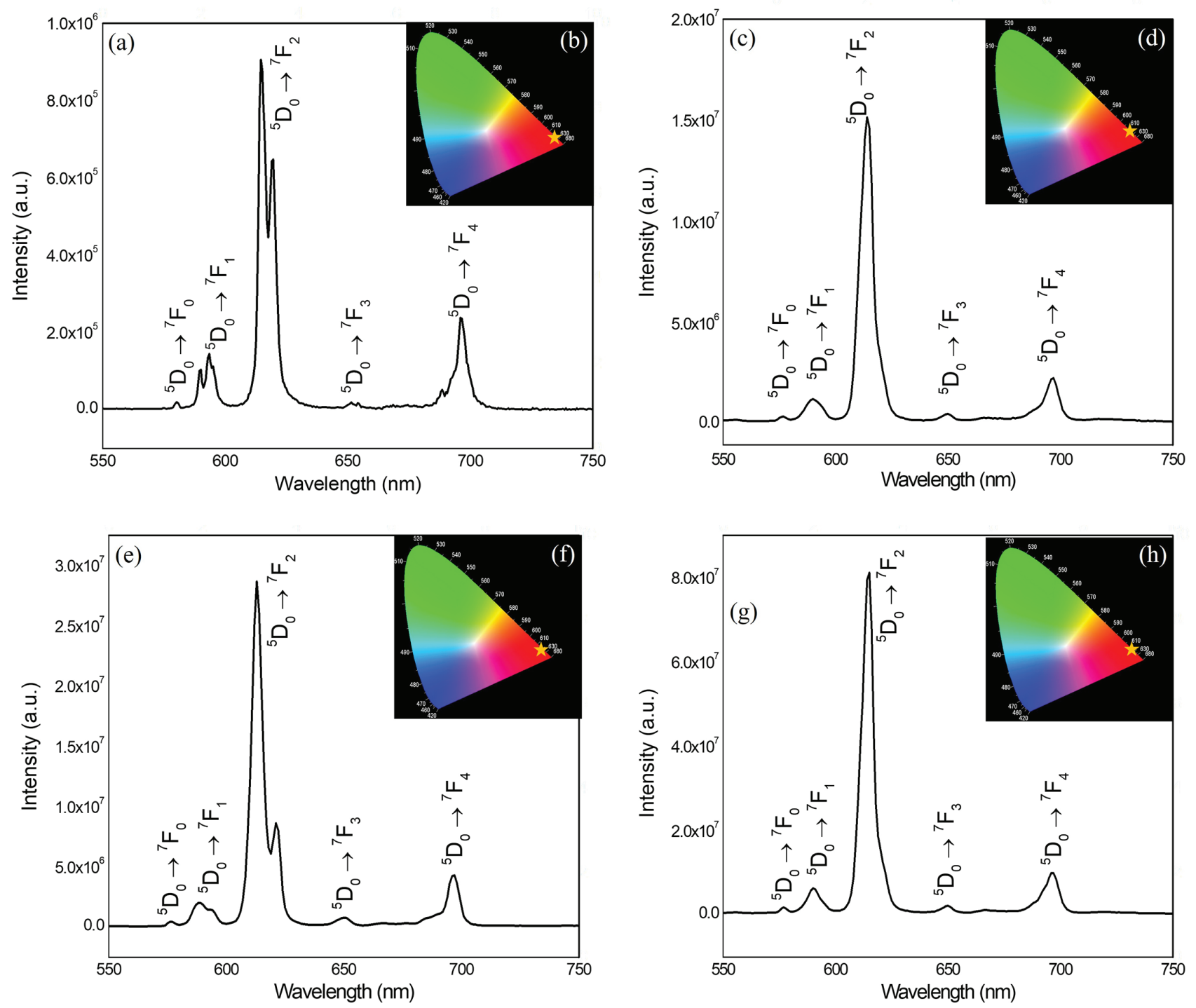

Figure 3. Emission spectra at room temperature, $\lambda_{\text {exc. }}=397 \mathrm{~nm}$, of (a) $\left[\mathrm{Eu}(\mathrm{pic})_{3} \cdot\left(\mathrm{H}_{2} \mathrm{O}\right)_{11}\right],(\mathrm{c})\left[\mathrm{Eu}(\mathrm{pic})_{3} \cdot(\mathrm{DVL})_{3}\right],(\mathrm{e})\left[\mathrm{Eu}(\mathrm{pic})_{3} \cdot(\mathrm{EPK})_{3}\right]$, and $(\mathrm{g})\left[\mathrm{Eu}(\mathrm{pic})_{3} \cdot(\mathrm{OEN})_{3}\right]$ and their respective chromaticity diagrams: (b) $\left[\mathrm{Eu}(\mathrm{pic})_{3} \cdot\left(\mathrm{H}_{2} \mathrm{O}\right)_{11}\right]$, (d) $\left[\mathrm{Eu}(\mathrm{pic})_{3} \cdot(\mathrm{DVL})_{3}\right]$, (f) $\left[\mathrm{Eu}(\mathrm{pic})_{3} \cdot(\mathrm{EPK})_{3}\right]$, and (h) $\left[\mathrm{Eu}(\mathrm{pic})_{3} \cdot(\mathrm{OEN})_{3}\right]$.

a highly polarizable chemical environment exists around the $\mathrm{Eu}^{\mathrm{III}}$. According to the literature, ${ }^{73}$ the $\Omega_{2}$ value is most influenced by small angular changes in the local geometry. This effect, together with changes in the polarizability of the ligating atom $(\alpha)$, has been used to explain the hypersensitivity of certain $4 \mathrm{f}-4 \mathrm{f}$ transitions to changes in the chemical environment. Borges et al. ${ }^{74}$ reported a new anionic complex containing 1-ethyl-3-methylimidazolium (EMIm) with the composition $(\mathrm{EMIm})_{2}\left[\mathrm{Eu}(\mathrm{Pic})_{4} \cdot\left(\mathrm{H}_{2} \mathrm{O}\right)_{2}\right] \mathrm{Pic}$ and found values for $\Omega_{2}\left(16.7 \times 10^{-20} \mathrm{~cm}^{2}\right)$ and $\Omega_{4}$ $\left(7.7 \times 10^{-20} \mathrm{~cm}^{2}\right)$. This is consistent with the values found for $\Omega_{2}$ and $\Omega_{4}$ in the present study for the compounds.

The red color of the synthesized compounds was verified using the chromaticity diagram in Figure 3 generated by the Spectra Lux 1.0 software, ${ }^{75}$ which used the emission spectra between $550-750 \mathrm{~nm}$. The following coordinates were obtained: $(x=0.68 ; y=0.31)$ for $\left[\mathrm{Eu}(\mathrm{pic})_{3} \cdot\left(\mathrm{H}_{2} \mathrm{O}\right)_{11}\right]$ in Figure 3b, $(x=0.67 ; y=0.32)$ for $\left[\mathrm{Eu}(\mathrm{pic})_{3} \cdot(\mathrm{DVL})_{3}\right]$ in Figure 3d, $(x=0.68 ; y=0.32)$ for $\left[\mathrm{Eu}(\mathrm{pic})_{3} \cdot(\mathrm{EPK})_{3}\right]$ in Figure $3 \mathrm{f}$, and $(x=0.68 ; y=0.32)$ for $\left[\mathrm{Eu}(\mathrm{pic})_{3} \cdot(\mathrm{OEN})_{3}\right]$ in Figure $3 \mathrm{~h}$. The values found for the chromaticity coordinates are in agreement with the standard values for red luminophores $(x=0.64 ; y=0.33) .{ }^{75,76}$

Photoluminescence analyses were qualitatively performed on the banknotes to visually assess the light emission of each complex present on the $\mathrm{R} \$ 50$ banknotes. Figure 4 shows the light emission of each complex under excitation at different wavelengths.

The emission of red light, corresponding to each complex present in the banknotes, under excitation at different wavelengths $(254,312,365$, and 320-400 nm (Lumatec Spritelite 400)) was easily visualized. These excitation 


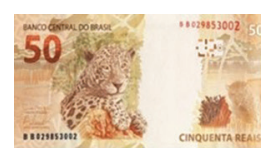

$254 \mathrm{~nm}$

$312 \mathrm{~nm}$

$365 \mathrm{~nm}$

Lumatec

Spirtelite

400
$\left[\mathrm{Eu}(\mathrm{Pic})_{3} \cdot(\mathrm{DVL})_{3}\right]$

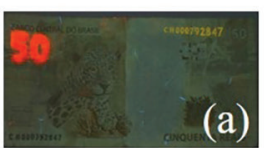

(a)
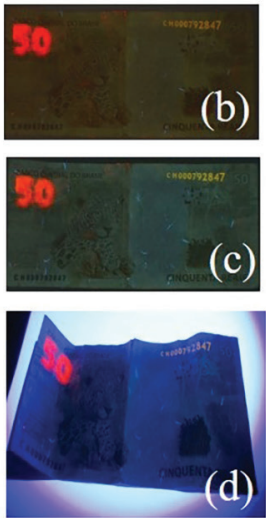

$\left[\mathrm{Eu}(\mathrm{Pic})_{3} \cdot(\mathrm{OEN})_{3}\right]$
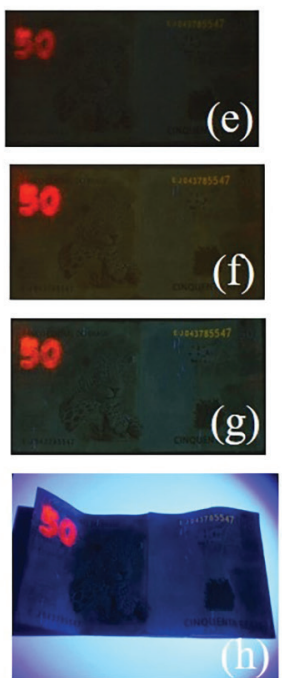

$\left[\mathrm{Eu}(\mathrm{Pic})_{3} \cdot(\mathrm{EPK})_{3}\right]$
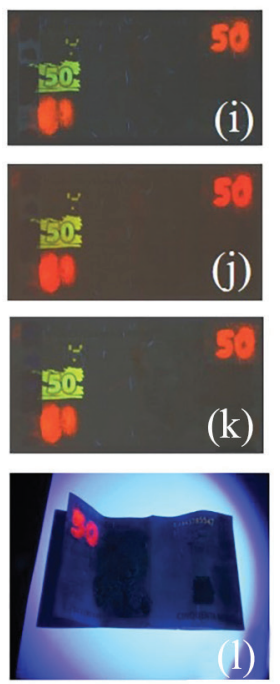

Figure 4. $\mathrm{R} \$ 50$ banknotes marked with three studied complexes under excitation at different wavelengths $(254,312,365$, and $320-400 \mathrm{~nm})$.

wavelengths were visually evaluated by observation of the emitted light from the complexes. At 365 and 320-400 nm, which are wavelengths close to that obtained in the excitation spectra $(397 \mathrm{~nm})$, the observed red light emission was more intense than that at the 254 and $312 \mathrm{~nm}$ wavelengths. In addition to the luminescence from the complexes added to the banknote surfaces, Figures $4 \mathrm{i}-4 \mathrm{k}$ also show a region of emitted green light, which is attributable to one of the security elements already present in the banknote itself.
While all the complexes produced light emissions that allowed their visual identification on banknotes, the $\left[\mathrm{Eu}(\mathrm{pic})_{3} \cdot(\mathrm{EPK})_{3}\right]$ complex was selected and applied on the surface of the $\mathrm{R} \$ 10, \mathrm{R} \$ 20$, and $\mathrm{R} \$ 100$ banknotes. Figure 5 shows the red light emission of the $\left[\mathrm{Eu}(\mathrm{pic})_{3} \cdot(\mathrm{EPK})_{3}\right]$ complex under excitation at different wavelengths on the $\mathrm{R} \$ 10, \mathrm{R} \$ 20$, and $\mathrm{R} \$ 100$ banknotes.

Based on the results in Figure 5, it was observed that the luminescence of the $\left[\mathrm{Eu}(\mathrm{pic})_{3} \cdot(\mathrm{EPK})_{3}\right]$ is visually

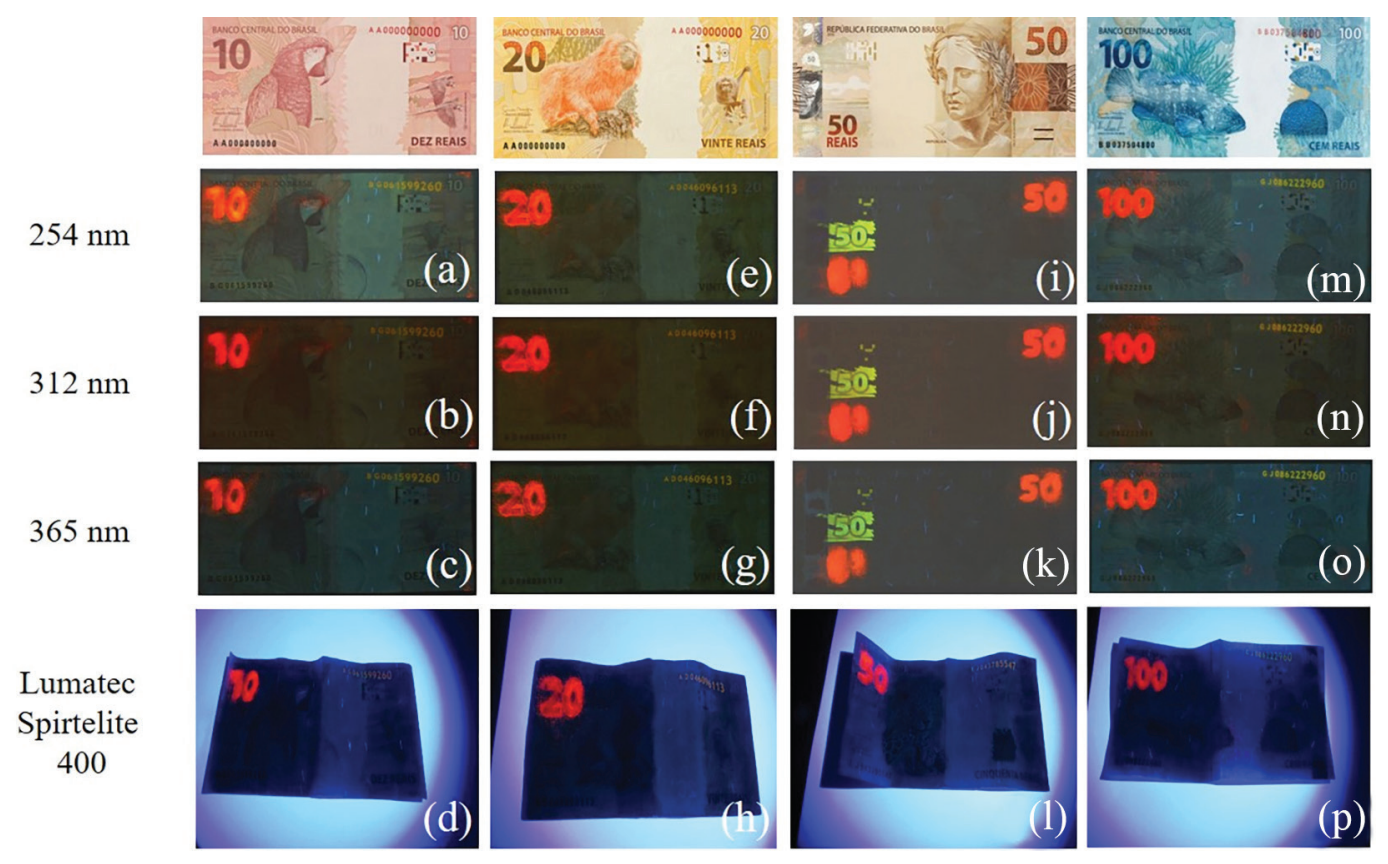

Figure 5. $\mathrm{R} \$ 10, \mathrm{R} \$ 20, \mathrm{R} \$ 50$ and $\mathrm{R} \$ 100$ banknotes marked with $1 \mathrm{mg}\left[\mathrm{Eu}(\mathrm{pic})_{3} \cdot(\mathrm{EPK})_{3}\right]$ under excitation at different wavelengths $(\lambda=254,312,365$, and $320-400 \mathrm{~nm}$ ). 
noticeable at different wavelengths. The $365 \mathrm{~nm}$ wavelength emits more intense luminescence because it is closer to the maximum excitation wavelength $(397 \mathrm{~nm})$ of the $\left[\mathrm{Eu}(\text { pic })_{3} \cdot(\mathrm{EPK})_{3}\right]$ complex.

\section{LDI ( \pm ) MS}

To identify the chemical profile of the complexes deposited on the banknote surfaces while preserving their integrity, the LDI $( \pm)$ MS technique was used, in which an analysis is made from the incidence of a laser beam (which may be pulsed ultraviolet or IR) focusing on a surface, allowing analyte desorption and ionization without the necessity of previous sample preparation. ${ }^{77-80}$ Figures $6 \mathrm{a}-6 \mathrm{~d}$ show the chemical profile of $\mathrm{R} \$ 50$ banknotes obtained by LDI (+) MS (Figure 6a) without Eu ${ }^{\mathrm{III}}$ complexes, and with (Figure 6b) $\left[\mathrm{Eu}(\mathrm{pic})_{3} \cdot(\mathrm{DVL})_{3}\right],($ Figure 6c) $\left[\mathrm{Eu}(\mathrm{pic})_{3} \cdot(\mathrm{EPK})_{3}\right]$, and (Figure 6d) $\left[\mathrm{Eu}(\mathrm{pic})_{3} \cdot(\mathrm{OEN})_{3}\right]$.

Figure 6a shows the chemical profile of the banknote with no complexes applied. It was observed that an ion of $\mathrm{m} / \mathrm{z} 575.08132$ is present. This ion is found abundantly in different regions of the $\mathrm{R} \$ 50$ banknotes before application of the complexes and thus can be characterized as a natural chemical marker to recognize the authenticity of banknotes. Eberlin et al. ${ }^{22}$ reported an analysis of Brazilian banknotes using DESI MS and EASI MS, identifying ions of $\mathrm{m} / \mathrm{z}, 391,413,429,803$ and 819 as natural markers that characterize the chemical profile of the authentic banknotes. Schmidt et al. ${ }^{81}$ also reported the study of a second family of real banknotes using EASI (+) MS, where the ion of $\mathrm{m} / \mathrm{z} 443$ was used as a fingerprint of authenticity.

LDI (+) MS spectra in Figures 6a-6d were obtained with mass resolution $\mathrm{m} / \Delta \mathrm{m}_{50 \%}$ ca. 381783 , where $\Delta \mathrm{m}_{50 \%}$ is the full peak width at half-maximum peak height and $\mathrm{m} / \mathrm{z}$ ca. $400,{ }^{82}$ and showed mass errors ranging from 0.76 to $4.64 \mathrm{ppm}$ as shown in Table 2. For the [Eu(pic) $\left.)_{3} \cdot(\mathrm{DVL})_{3}\right]$ complex, with molecular formula $(\mathrm{M})=\mathrm{EuC}_{33} \mathrm{H}_{33} \mathrm{~N}_{12} \mathrm{O}_{24}$ and molecular weight $\left(\mathrm{M}_{\mathrm{w}}\right)=1134 \mathrm{Da}$, LDI $(+) \mathrm{MS}$ analysis (Figure 6b) showed a signal representing the ion of $m / 2$ 906.10605, $\left[\mathrm{EuC}_{27} \mathrm{H}_{31} \mathrm{~N}_{9} \mathrm{O}_{17}\right]^{+}$, double bond equivalent

(a)

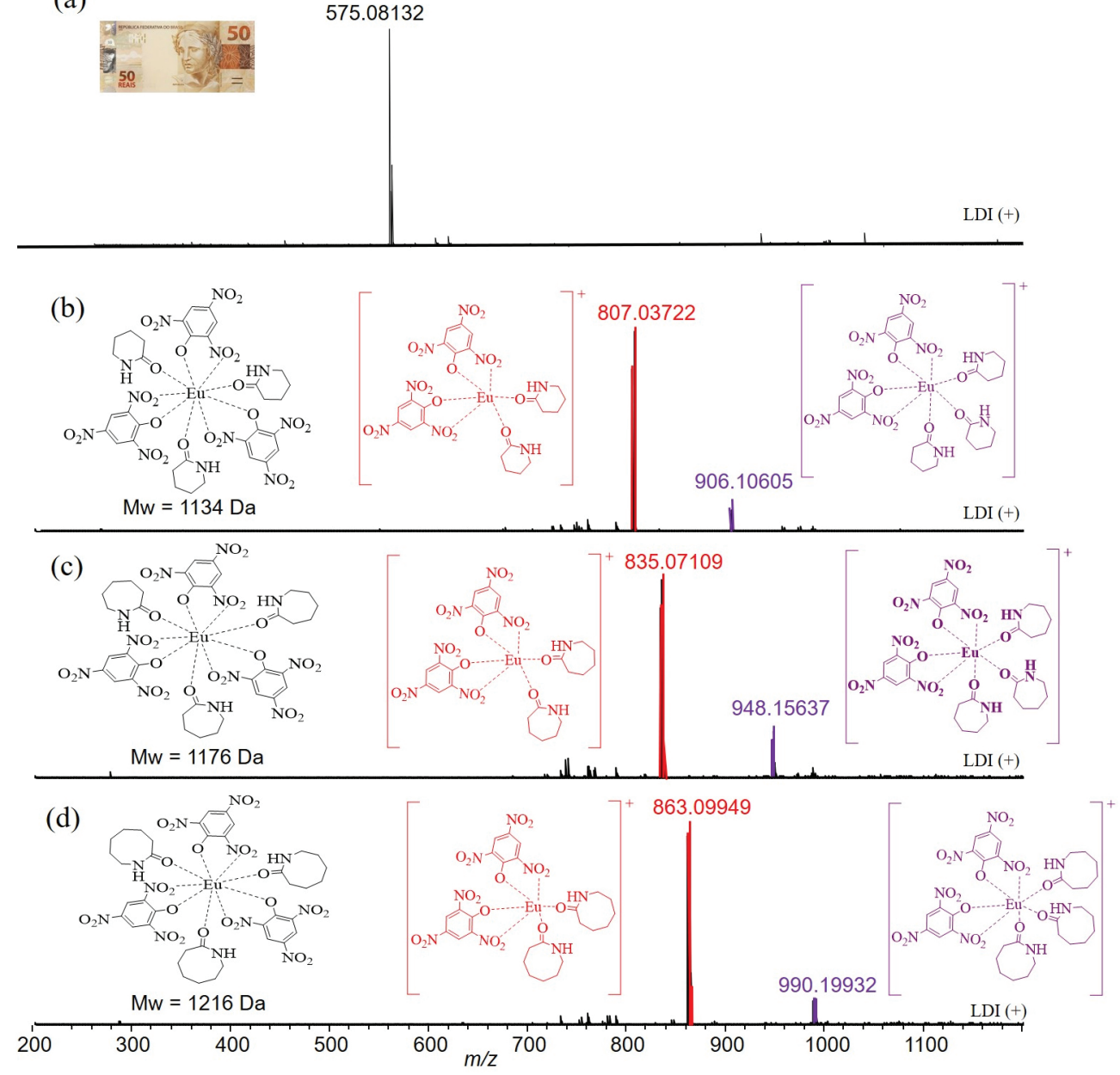

575.08132

Figure 6. Chemical profile of $\mathrm{R} \$ 50$ banknotes obtained by LDI (+) MS (a) without Eu ${ }^{\mathrm{III}}$ complexes, and with (b) $\left[\mathrm{Eu}(\mathrm{pic})_{3} \cdot(\mathrm{DVL})_{3}\right]$, (c) $\left[\mathrm{Eu}(\mathrm{pic})_{3} \cdot(\mathrm{EPK})_{3}\right]$, and $(\mathrm{d})\left[\mathrm{Eu}(\mathrm{pic})_{3} \cdot(\mathrm{OEN})_{3}\right]$. 
Table 2. Molecular formulas, measured and theoretical mass values, mass errors, and DBE for $\left[\mathrm{Eu}(\mathrm{pic})_{3} \cdot(\mathrm{DVL})_{3}\right],\left[\mathrm{Eu}(\mathrm{pic})_{3} \cdot(\mathrm{EPK})_{3}\right]$, and $\left[\mathrm{Eu}(\mathrm{pic})_{3} \cdot(\mathrm{OEN})_{3}\right]$ complexes identified by LDI (+) MS

\begin{tabular}{|c|c|c|c|c|c|}
\hline Compound & Molecular formula & $\mathrm{m} / \mathrm{z}$ measured & $\mathrm{m} / \mathrm{z}$ theoretical & Error / ppm & DBE \\
\hline \multirow{2}{*}[\mathrm{Eu}(\mathrm{pic})_{3}\cdot(\mathrm{DVL})_{3}]{} & {$\left[\mathrm{EuC}_{27} \mathrm{H}_{31} \mathrm{~N}_{9} \mathrm{O}_{17}\right]^{+}$} & 906.10605 & 906.10502 & 1.13 & 17 \\
\hline & {$\left[\mathrm{EuC}_{22} \mathrm{H}_{22} \mathrm{~N}_{8} \mathrm{O}_{16}\right]^{+}$} & 807.03722 & 807.03660 & 0.76 & 16 \\
\hline \multirow{2}{*}[\mathrm{Eu}(\mathrm{pic})_{3}\cdot(\mathrm{EPK})_{3}]{} & {$\left[\mathrm{EuC}_{30} \mathrm{H}_{37} \mathrm{~N}_{9} \mathrm{O}_{17}\right]^{+}$} & 948.15637 & 948.15197 & 4.64 & 17 \\
\hline & {$\left[\mathrm{EuC}_{24} \mathrm{H}_{26} \mathrm{~N}_{8} \mathrm{O}_{16}\right]^{+}$} & 835.07109 & 835.06790 & 3.82 & 16 \\
\hline \multirow{2}{*}[\mathrm{Eu}(\mathrm{pic})_{3}\cdot(\mathrm{OEN})_{3}]{} & {$\left[\mathrm{EuC}_{33} \mathrm{H}_{43} \mathrm{~N}_{9} \mathrm{O}_{17}\right]^{+}$} & 990.19932 & 990.19892 & 0.40 & 17 \\
\hline & {$\left[\mathrm{EuC}_{26} \mathrm{H}_{30} \mathrm{~N}_{8} \mathrm{O}_{16}\right]^{+}$} & 863.09949 & 863.09920 & 0.33 & 16 \\
\hline
\end{tabular}

DBE: double bond equivalent; pic: picrate anion; DVL: delta-valerolactam; EPK: epsilon-caprolactam; OEN: oenantholactam.

$(\mathrm{DBE})=17$, which represents the loss of a picrate molecule in the form of picric acid, $\mathrm{C}_{6} \mathrm{H}_{3} \mathrm{~N}_{3} \mathrm{O}_{7}(228 \mathrm{Da})$ from the original formula, thus allowing the ionization to occur. An ion of $m / z$ 807.03722, $\left[\mathrm{EuC}_{22} \mathrm{H}_{22} \mathrm{~N}_{8} \mathrm{O}_{16}\right]^{+}, \mathrm{DBE}=16$ is also observed, which originates from the loss of a DVL molecule, $\mathrm{M}=\mathrm{C}_{5} \mathrm{H}_{9} \mathrm{NO}$ (99 Da), from the ion of $\mathrm{m} / \mathrm{z}$.906.10605.

For the $\left[\mathrm{Eu}(\mathrm{pic})_{3} \cdot(\mathrm{EPK})_{3}\right]$ complex (Figure 6c), for which $\mathrm{M}=\mathrm{EuC}_{36} \mathrm{H}_{39} \mathrm{~N}_{12} \mathrm{O}_{24}$ and $\mathrm{M}_{\mathrm{w}}=1176 \mathrm{Da}$, the loss of a picrate molecule in the form of picric acid, $\mathrm{M}=\mathrm{C}_{6} \mathrm{H}_{3} \mathrm{~N}_{3} \mathrm{O}_{7}$ (228 Da), is detected, forming an ion of $\mathrm{m} / \mathrm{z}$ 948.15637, $\left[\mathrm{EuC}_{30} \mathrm{H}_{37} \mathrm{~N}_{9} \mathrm{O}_{17}\right]^{+}$, and $\mathrm{DBE}=17$. The formation of an ion of $\mathrm{m} / \mathrm{z}$ 835.07109, $\left[\mathrm{EuC}_{24} \mathrm{H}_{26} \mathrm{~N}_{8} \mathrm{O}_{16}\right]^{+}$, and $\mathrm{DBE}=16$ was also observed, originating from the loss of an EPK molecule, $\mathrm{M}=\mathrm{C}_{5} \mathrm{H}_{11} \mathrm{NO}\left(\mathrm{M}_{\mathrm{w}}=113 \mathrm{Da}\right)$, from the ion of $m / z 948.15637$.

For the $\left[\mathrm{Eu}(\text { pic })_{3} \cdot(\mathrm{OEN})_{3}\right]$ complex, with $\mathrm{M}=\mathrm{EuC}_{39} \mathrm{H}_{45} \mathrm{~N}_{12} \mathrm{O}_{24}$ and $\mathrm{M}_{\mathrm{w}}=1216 \mathrm{Da}$, LDI (+) MS analysis (Figure 6d) shows that the loss of a picrate molecule in the form of picric acid, $\mathrm{M}=\mathrm{C}_{6} \mathrm{H}_{3} \mathrm{~N}_{3} \mathrm{O}_{7}\left(\mathrm{M}_{\mathrm{w}}=228 \mathrm{Da}\right)$, produces an ion of $m / z$ 990.19932, $\left[\mathrm{EuC}_{33} \mathrm{H}_{43} \mathrm{~N}_{9} \mathrm{O}_{17}\right]^{+}$, and $\mathrm{DBE}=17$. The signal observed at $\mathrm{m} / \mathrm{z}$ 863.09949, $\left[\mathrm{EuC}_{26} \mathrm{H}_{30} \mathrm{~N}_{8} \mathrm{O}_{16}\right]^{+}$, and $\mathrm{DBE}=16$ originated from the loss of an OEN molecule, $\mathrm{M}=\mathrm{C}_{7} \mathrm{H}_{13} \mathrm{NO}(127 \mathrm{Da})$.

LDI mass spectra in negative ionization mode, i.e., LDI (-) MS, for three complexes are shown in Figure S3 (SI section), presenting the same chemical profiles, which identify only the presence of the signal related to the ion of $m / z$ 1064.87567, $\left[\mathrm{EuC}_{24} \mathrm{H}_{8} \mathrm{~N}_{12} \mathrm{O}_{28}\right]^{-}$with error $=2.48 \mathrm{ppm}$ and DBE $=27$. The results obtained by LDI (-) MS for the three complexes, shown in Figure S3, resembled the ESI (-) Fourier transform ion cyclotron resonance (FTICR) MS chemical profile of a europium picrate complex with $N$-methylcaprolactam, $\mathrm{M}=\mathrm{Eu}(\mathrm{PIC})_{3}(\mathrm{NMK})_{3}$, and an ion of $m / z$. 1064.87567, $\left[\mathrm{EuC}_{24} \mathrm{H}_{8} \mathrm{~N}_{12} \mathrm{O}_{28}\right]^{-}$, as reported by Destefani et al.$^{83}$ For the LDI $( \pm)$ mass spectra of the banknotes marked with complexes, the signal of the ion of $\mathrm{m} / \mathrm{z} 575.08132$ (unmarked banknote) has been suppressed by signals coming from the complexes.
The isotopologue patterns of the experimental and theoretical signals of $\mathrm{m} / \mathrm{z}, 906.10605,807.03722$, $948.15637,835.07109,990.19932$, and 863.09949 in the LDI (+) MS spectra (Figure 7) were compared and showed good agreement, thus confirming the presence of $\mathrm{Eu}^{\mathrm{III}}$ complexes in the studied banknotes.

\section{Conclusions}

In this study, the $\left[\mathrm{Eu}(\mathrm{pic})_{3} \cdot(\mathrm{DVL})_{3}\right],\left[\mathrm{Eu}(\mathrm{pic})_{3} \cdot(\mathrm{EPK})_{3}\right]$, and $\left[\mathrm{Eu}(\text { pic })_{3} \cdot(\mathrm{OEN})_{3}\right]$ complexes were shown as new potential luminescent security materials for application in questioned documents. The identification of the complexes on the banknotes can be easily performed because wavelengths in the UV region can be used to produce light emission by the complexes. It was also possible to identify the complexes present on the surface of the banknotes using the non-destructive LDI ( \pm ) MS technique. Finally, the average cost for the synthesis of the complexes was $\mathrm{R} \$ 0.65$ per $\mathrm{mg}$.

\section{Supplementary Information}

Supplementary data (UV-Vis, excitation spectra, and LDI (-) MS) are available free of charge at http://jbcs.sbq.org.br as a PDF file.

\section{Acknowledgments}

The authors thank CAPES (23038.007083/2014-40), FAPES (edital CNPq/FAPES No. 23/2018, Programa de Apoio a Núcleos Emergentes (PRONEM)), and CNPq (422555/2018-5 and 305359/2017-7) for financial support. The authors would also like to thank the Núcleo de Competências em Química do Petróleo and LabPetro for the use of their installations. This study was financed in part by the Coordenação de Aperfeiçoamento de Pessoal de Nível Superior Brazil (CAPES) finance code 1. 
(a) $\left[\mathrm{EuC}_{27} \mathrm{H}_{31} \mathrm{~N}_{9} \mathrm{O}_{17}\right]^{+}$

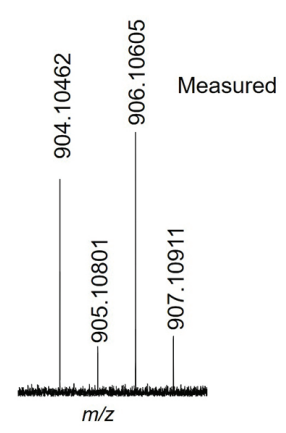

(b) $\left[\mathrm{EuC}_{22} \mathrm{H}_{22} \mathrm{~N}_{8} \mathrm{O}_{16}\right]^{+}$

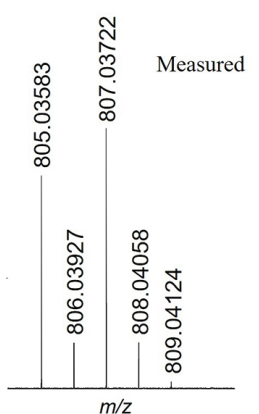

(c) $\left[\mathrm{EuC}_{30} \mathrm{H}_{37} \mathrm{~N}_{9} \mathrm{O}_{17}\right]^{+}$
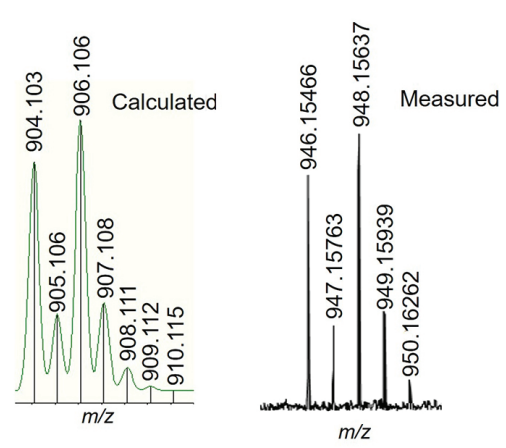

(d) $\left[\mathrm{EuC}_{24} \mathrm{H}_{26} \mathrm{~N}_{8} \mathrm{O}_{16}\right]^{+}$

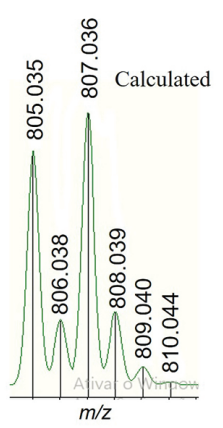

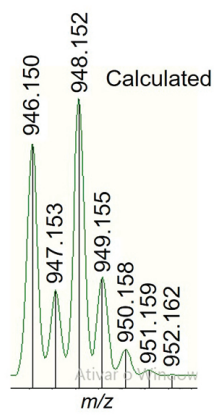
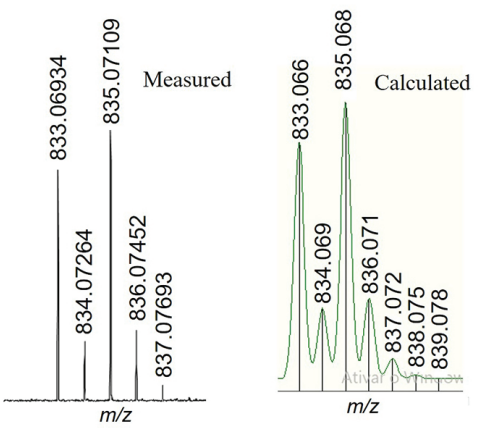

(e) $\left[\mathrm{EuC}_{33} \mathrm{H}_{43} \mathrm{~N}_{9} \mathrm{O}_{17}\right]^{+}$
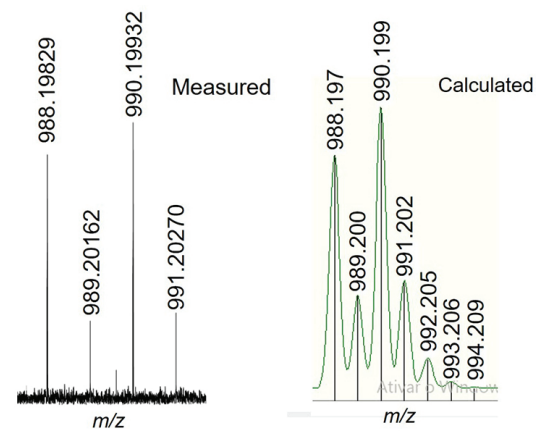

(f) $\left[\mathrm{EuC}_{26} \mathrm{H}_{30} \mathrm{~N}_{8} \mathrm{O}_{16}\right]^{+}$

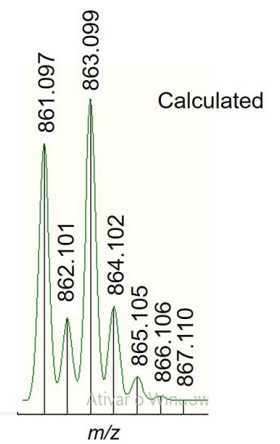

Figure 7. Experimental and calculated isotopologue patterns of (a) $\left[\mathrm{EuC}_{27} \mathrm{H}_{31} \mathrm{~N}_{9} \mathrm{O}_{17}\right]^{+}$, (b) $\left[\mathrm{EuC}_{22} \mathrm{H}_{22} \mathrm{~N}_{8} \mathrm{O}_{16}\right]^{+}$, (c) $\left[\mathrm{EuC}_{30} \mathrm{H}_{37} \mathrm{~N}_{9} \mathrm{O}_{17}\right]^{+}$, (d) $\left[\mathrm{EuC} \mathrm{Cu}_{24} \mathrm{H}_{26} \mathrm{~N}_{8} \mathrm{O}_{16}\right]^{+}$, (e) $\left[\mathrm{EuC}_{33} \mathrm{H}_{43} \mathrm{~N}_{9} \mathrm{O}_{17}\right]^{+}$, and (f) $\left[\mathrm{EuC}_{26} \mathrm{H}_{30} \mathrm{~N}_{8} \mathrm{O}_{16}\right]^{+}$complexes.

\section{Author Contributions}

Clebson de J. Macrino was responsible for the conceptualization, data curation, formal analysis, investigation, methodology, visualization, writing the original draft, review, and editing; Elias M. Silva for the conceptualization, data curation, formal analysis, investigation, methodology, visualization, writing the original draft, and review; Victor R. Cunha for the formal analysis, investigation, and writing the original draft; Victor R. Fonseca for the formal analysis, investigation, and writing the original draft; Álvaro Cunha Neto for the conceptualization, data curation, formal analysis, investigation, methodology, visualization, writing the original draft, and review; Joyce R. Araújo for the formal analysis, investigation, and writing the original draft; Valdemar Lacerda Jr. and Wanderson Romão were responsible for the conceptualization, funding acquisition, investigation, methodology, project administration, resources, supervision, visualization, writing the original draft, review, and editing.

\section{References}

1. Valderrama, L.; Valderrama, P.; Chemom. Intell. Lab. Syst. 2016, $156,188$.
2. Hoyo-Meléndez, J. M.; Gondko, K.; Mendys, A.; Król, M.; Klisinska-Kopacz, A.; Sobczyk, J.; Jaworucka-Drath, A.; Forensic Sci. Int. 2016, 266, 329.

3. Bozicevic, M. S.; Gajovic, A.; Zjakic, I.; Forensic Sci. Int. 2012, 223, 314.

4. Saini, K.; Kaur, S.; Egypt. J. Forensic Sci. 2016, 6, 317.

5. Herrero, L. O.; Blanco, M. E.; García-Ruiz, C.; Bartolomé, L.; J. Anal. Appl. Pyrolysis 2018, 131, 9.

6. Silva, C. S.; Pimentel, M. F.; Amigo, J. M.; Ruiz, C. G.; Ojeda, F. O.; Anal. Chim. Acta 2018, 1031, 28.

7. Kaur, R.; Saini, K.; Sood, N. C.; Sci. Justice 2013, 53, 212.

8. Silva, V. A. G.; Talhavini, M.; Peixoto, I. C. F.; Zacca, J. J.; Maldaner, A. O.; Braga, J. W. B.; Microchem. J. 2014, 116, 235.

9. Joshi, M. C.; Kumar, A.; Thakur, S.; Probl. Forensic Sci. 2011, $56,162$.

10. Brandão, J. M. O. B.; Almeida, N. S. M.; Dixini, P. V. M.; Baier, C. H. A.; Dias, H. P.; Bassane, J. F. P.; França, H. S.; Silva, S. R. C.; Aquije, G. M. F. V.; Romão, W.; Anal. Methods 2016, 8, 771.

11. Correia, R. M.; Domingos, E.; Tosato, F.; Aquino, L. F. M.; Fontes, A. M.; Cao, V. M.; Filgueiras, P. R.; Romão, W.; Forensic Chem. 2018, 8, 57.

12. Braz, A.; López, M. L.; Ruiz, C. G.; Forensic Sci. Int. 2013, 232, 206.

13. Teixeira, C. A.; Poppi, R. J.; Microchem. J. 2019, 144, 411. 
14. Almeida, M. R.; Correa, D. N.; Rocha, W. F. C.; Scafi, F. J. O.; Poppi, R. J.; Microchem. J. 2013, 109, 170.

15. Marise, C.; Ross, P.; Forensic Sci. Int. 2011, 206, 207.

16. Williams, M. R.; Moody, C.; Arceneaux, L. A.; Rinke, C.; White, K.; Sigman, M. E.; Forensic Sci. Int. 2009, 191, 97.

17. Correa, D. N.; Zacca, J. J.; Rocha, W. F. C.; Borges, R.; Souza, W.; Augusti, R.; Eberlin, M. N.; Vendramini, P. H.; Forensic Sci. Int. 2016, 260, 22.

18. Gallidabino, M.; Weyermann, C.; Marquis, R.; Forensic Sci. Int. 2011, 204, 169.

19. Weyermann, C.; Kirsch, D.; Vera, C. C.; Spengler, B.; J. Am. Soc. Mass Spectrom. 2006, 17, 297.

20. Domingos, E.; Carvalho, T. C.; Pereira, I.; Vasconcelos, G. A.; Thompson, C. J.; Augusti, R.; Rodrigues, R. R. T.; Tose, L. V.; Santos, H.; Araujo, J. R.; Vaz, B. G.; Romão, W.; Anal. Methods 2017, 9, 4400 .

21. Ferreira, P. S.; Silva, D. F. A.; Augusti, R.; Piccin, E.; Analyst 2015, 140, 811.

22. Eberlin, L. S.; Haddad, R.; Neto, R. C. S.; Cosso, R. G.; Maia, D. R. J.; Maldaner, A. O.; Zacca, J. J.; Sanvido, G. B.; Romão, W.; Vaz, B. G.; Ifa, D. R.; Dill, A.; Cooks, R. G.; Eberlin, M. N.; Analyst 2010, 135, 2533.

23. Ifa, D. R.; Wiseman, J. M.; Song, Q.; Cooks, R. G.; Int. J. Mass Spectrom. 2007, 259, 8.

24. Schmidt, E. M.; Franco, M. F.; Regino, K. G.; Lehmann, E. L.; Arruda, M. A. Z.; Rocha, W. F. C.; Borges, R.; Souza, W.; Eberlin, M. N.; Correa, D. N.; Sci. Justice 2014, 54, 459.

25. Jara, M. A. Z.; Obregón, C. L.; del Castillo, C. A.; Appl. Radiat. Isot. 2018, 135, 212.

26. Guo, H.; Yin, B.; Zhang, J.; Quan, Y.; Shi, G.; Forensic Sci. Int. 2016, 266, 43.

27. Oliveira, V. S.; Honorato, R. S.; Honorato, F. A.; Pereira, C. F.; Forensic Sci. Int. 2018, 286, 121.

28. He, N.; Gao, M.; Shen, D.; Li, H.; Han, Z.; Zhao, P.; Forensic Sci. Int. 2019, 297, 1.

29. Shao, J.; Yan, J.; Li, X.; Li, S.; Hu, T.; Dyes Pigm. 2019, 160, 555.

30. Serwy, I. B.; Wanderley, K. A.; Lucena, M. A. M.; Maldaner, A. O.; Talhavini, M.; Rodrigues, M. O.; Weber, I. T.; J. Lumin. 2018, 200, 24

31. Lucena, M. A. A.; Arouca, A. M.; Talhavini, M.; Alves-Júnior, S.; Weber, I. T.; Microchem. J. 2019, 145, 539.

32. Silva, J. Y. R.; Luz, L. L.; Maurício, F. G. M.; Alves, I. B. V.; Ferro, J. N. S.; Barreto, E.; Weber, I. T.; Azevedo, W. M.; Junior, S. A.; ACS Appl. Mater. Interfaces 2017, 9, 16458.

33. Maurício, F. G. M.; Pralon, A. Z.; Talhavini, M.; Rodrigues, M. O.; Weber, I. T.; Forensic Sci. Int. 2017, 275, 8.

34. Arouca, A. M.; Lucena, M. A. M.; Rossiter, R. J.; Talhavini, M.; Weber, I. T.; Forensic Sci. Int. 2017, 281, 161.

35. Lucena, M. A. M.; Ordoñez, C.; Weber, I. T.; Torre, M.; Ruiz, C. G.; López, M. L.; Forensic Sci. Int. 2017, 280, 95.
36. Lucena, M. A. M.; Rodrigues, M. O.; Gatto, C. C.; Talhavini, M.; Maldaner, A. O.; Alves Jr., S.; Weber, I. T.; J. Lumin. 2016, 170, 697 .

37. Lucena, M. A. M.; Oliveira, M. F. L.; Arouca, A. M.; Talhavini, M.; Ferreira, E. A.; Alves, S.; Souza, F. H. V.; Weber, I. T.; ACS Appl. Mater. Interfaces 2017, 9, 4691.

38. Weissman, S. J.; J. Chem. Phys. 1942, 10, 214.

39. Andrade, A. V. M.; da Costa Jr., N. B.; Simas, A. M.; Longo, R. L.; Malta, O. L.; Sá, G. F.; Quim. Nova 1998, 21, 51.

40. Martins, T. S.; Isolani, P. C.; Quim. Nova 2005, 28, 111.

41. Liu, N.; Inorg. Chem. Commun. 2019, 103, 113.

42. Hong, Z.; Li, W.; Zhao, D.; Liang, C.; Liu, X.; Peng, J.; Zhao, D.; Synth. Met. 1999, 104, 165.

43. Wang, S.; Wang, L.; TrAC, Trends Anal. Chem. 2014, 62, 123.

44. Tu, D.; Zheng, W.; Liu, Y.; Zhu, H.; Chen, X.; Coord. Chem. Rev. 2014, 273, 13.

45. Guo, L.; Zhang, X.; Yang, D.; Liang, H.; Wang, Y.; J. Lumin. 2019, 116610.

46. Xiang, W.; Wang, Z.; Kubicki, D. J.; Tress, W.; Luo, J.; Prochowicz, D.; Akin, S.; Emsley, L.; Zhou, J.; Dietler, G.; Gratzel, M.; Hagfeldt, A.; Joule 2019, 3, 205.

47. Koshelev, D. S.; Chikineva, T. Y.; Kozhevnikova, V. Y.; Medvedko, A. V.; Vashchenko, A. A.; Goloveshkin, A. S.; Tsymbarenko, D. M.; Averin, A. A.; Meschkov, A.; Schepers, U.; Vatsadze, S. Z.; Utochnikova, V. V.; Dyes Pigm. 2019, 170, 107604.

48. Park, S. J.; Je, B. S.; Jang, J. W.; Oh, M. S.; Koo, M. S.; Yang, S. J.; Yang, H. K.; J. Alloys Compd. 2019, 789, 367.

49. Shahi, P. K.; Singh, P.; Singh, A. K.; Singh, S. K.; Rai, S. B.; Prakash, R.; J. Colloid Interface Sci. 2017, 491, 199.

50. Silva, M. A.; Campos, N. R.; Ferreira, L. A.; Flores, L. S.; Júnior, J. C. A.; Santos, G. L.; Correa, C. C.; Santos, T. C.; Ronconi, C. M.; Colaço, M. V.; Simões, T. R. G.; Marques, L. F.; Marinho, M. V.; Inorg. Chim. Acta 2019, 495, 118967.

51. Junior, J. C. A.; Santos, G. L.; Colaco, M. C.; Barroso, R. C.; Ferreira, F. F.; Santos, M. V.; Campos, N. R.; Jesus, L. T.; Freire, R. O.; Marques, L. F.; J. Phys. Chem. C 2020, 124, 9996.

52. Silva, A. G.; Vicentini, G.; Zukerman-Schpector, J.; Castellano, E. E.; J. Alloys Compd. 1995, 225, 354.

53. Miranda Jr., P.; Carvalho, C. C.; Zukerman-Schpector, J.; Isolani, P. C.; Vicentini, G.; Zinner, L. B.; J. Alloys Compd. 2000, 303, 162.

54. Melo, C. V. P.; Vicentini, G.; Isolani, P. C.; Zukerman-Schpector, J.; Castellano, E. E.; J. Alloys Compd. 1998, 275, 242.

55. Nunes, C. C. F.; Zinner, K.; Zinner, L. B.; Carvalho, C. C.; Zukerman-Schpector, J.; Vicentini, G.; Inorg. Chim. Acta 1999, 292, 249.

56. Marinho, E. P.; Melo, D. M. A.; Zinner, L. B.; Vicentini, G.; Zukerman-Schpector, J.; Zinner, K.; J. Alloys Compd. 2000, $303,116$.

57. Destefani, C. A.; Motta, L. C.; Costa, R. A.; Macrino, C. J.; Bassane, J. F. P.; Filho, J. F. A.; Silva, E. M.; Greco, S. 
J.; Carneiro, M. T. W. D.; Endringer, D. C.; Romão, W.; Microchem. J. 2016, 124, 195.

58. Lyle, S. J.; Rahaman, M. M.; Talanta 1963, 10, 1177.

59. Nakagawa, K.; Amita, K.; Mizuno, H.; Inoue, Y.; Hakushi, T.; Bull. Chem. Soc. Jpn. 1987, 60, 2037.

60. Marinho, E. P.; Melo, D. M. A.; Zinner, L. B.; Zinner, K.; Matos, J. E. X.; J. Alloys Compd. 1998, 275, 795.

61. Assunção, L. M.; Ionashiro, M.; Rasera, D. E.; Giolito, I.; Thermochim. Acta 1993, 219, 225.

62. Saleh, M. I.; Kusrini, E.; Fun, H. K.; Yamin, B. M.; J. Organomet. Chem. 2008, 693, 2561.

63. Martins, T. S.; Araujo, A. A. S.; Araujo, M. P. B. M.; Isolani, P. C.; Vicentini, G.; J. Alloys Compd. 2002, 344, 75.

64. Wang, Y. W.; Liu, W. S.; Tang, N.; Tan, M. Y.; Yu, K. B.; J. Mol. Struct. 2003, 660, 41.

65. Marinho, E. P.; Melo, D. M. A.; Zinner, L. B.; Zinner, K.; Castellano, E. E.; Schpector, J. Z.; Isolani, P. C.; Vicentin, G.; Polyhedron 1997, 16, 3519.

66. Carnall, W. T.; Fields, P. R.; Rajnak, K.; J. Chem. Physics 1968 , 49, 4450.

67. Forsberg, J. H.; Coord. Chem. Rev. 1973, 10, 195.

68. Ferreira, R. A. S.; Nobre, S. S.; Granadeiro, C. M.; Nogueira, H. I. S.; Carlos, L. D.; Malta, O. L.; J. Lumin. 2006, 121, 561.

69. Sá, G. F.; Malta, O. L.; Donegá, C. M.; Simas, A. M.; Longo, R. L.; Santa-Cruz, P. A.; Silva Jr., E. F.; Coord. Chem. Rev. 2000, 196, 165.

70. Borges, A. S.; Fulgêncio, F.; Silva, J. G.; Santos, T. A. R.; Diniz, R.; Windmöller, D.; Magalhães, W. F.; Araujo, M. H.; J. Lumin. 2019, 205, 72.

71. Pavithran, R.; Kumar, N. S. S.; Biju, S.; Reddy, M. L. P.; Junior, S. A.; Freire, R. O.; Inorg. Chem. 2006, 45, 2184.

72. Costa, J. A. S.; Jesus, R. A.; Dorst, D. D.; Pinatti, I. M.; Oliveira, L. M. R.; Mesquita, M. E.; Paranhos, C. M.; J. Lumin. 2017, 192,1149 .
73. Borges, A. S.; Caliman, E. V.; Dutra, J. D. L.; Silva, J. G.; Araujo, M. H.; J. Lumin. 2016, 170, 654.

74. Borges, A. S.; Silva, J. G.; Ayala, J. D.; Dutra, J. D. L.; Speziali, N. L.; Brito, H. F.; Araujo, M. H.; Spectrochim. Acta, Part A 2014, 117, 718.

75. Santa-Cruz, P. A.; Teles, F. S.; Spectra Lux Software v. 1.0; Ponto Quântico Nanodispositivos/RENAMI, Recife, PE, Brazil, 2003.

76. Venturini Filho, E.; de Sousa Filho, P. C.; Serra, O. A.; Weber, I. T.; Lucena, M. A. M.; Luz, P. P.; J. Lumin. 2018, 202, 89.

77. Almeida, C. M.; Sales, D. D.; Tosato, F.; Santos, N. A.; Filho, J. F. A.; Macrino, C. J.; Pinto, F. E.; Filgueiras, P. R.; Romão, W.; Microchem. J. 2019, 148, 220.

78. Santos, N. A.; Souza, L. M.; Pinto, F. E.; Macrino, C. J.; Almeida, C. M.; Merlo, B. B.; Filgueiras, P. R.; Ortiz, R. S.; Borges, R. M.; Romão, W.; Anal. Methods 2019, 11, 1764.

79. Almeida, C. M.; Pinto, F. E.; Santos, N. A.; Souza, L. M.; Merlo, B. B.; Thompson, C. J.; Romão, W.; Microchem. J. 2019, 149 , 104002.

80. Falco, L. F. G.; Melo, C. F. O. R.; Oliveira, D. N.; Guerreiro, T. M.; Catharino, R. R.; Talanta 2019, 197, 92.

81. Schmidt, E. M.; Franco, M. F.; Cuelbas, C. J.; Zacca, J. J.; Rocha, W. F. C.; Borges, R.; Souza, W.; Sawaya, A. C. H. F.; Eberlin, M. N.; Correa, D. N.; Sci. Justice 2015, 55, 285.

82. Colati, K. A. P.; Dalmaschio, G. P.; Castro, E. V. R.; Gomes, A. O.; Vaz, B. G.; Romão, W.; Fuel 2013, 108, 647.

83. Destefani, C. A.; Motta, L. C.; Vanini, G.; Souza, L. M.; Filho, J. F. A.; Macrino, C. J.; Silva, E. M.; Greco, S. J.; Endringer, D. C.; Romão, W.; Microchem. J. 2014, 116, 216.

Submitted: August 8, 2020 Published online: January 19, 2021 